\title{
Viva eterno Leopoldo! Italian Birthday Serenatas by Johann Heinrich Schmelzer
}

\author{
Petr Slouka / slouka@lobkowicz.cz
}

The Lobkowicz Collections, Prague and Nelahozeves / Department of Musicology, Faculty of Arts, Masaryk University, Brno, CZ

\begin{abstract}
Both, secular as well as spiritual dramatic compositions by Johann Heinrich Schmelzer (1620/23-1680) represent only a fraction of the composer's work. Though its research brings rather surprising findings within the field of style problematic, it also helps to create a comprehensive view on opera and oratorio performances at the Imperial court. In the preserved serenata Le veglie ossequiose from 1679 we can see hints of distinctive synthesis of his compositional style with that of Antonio Draghi (1634/35-1700). Despite the fact, that the score for Schmelzer's first Italian serenata L'urna della sorte is not preserved, its printed libretto represents an interesting source, which can be used as an important comparative material. Therefore, the goal of this paper is to summarize the existing findings and compare them with analysis of preserved music and librettos.
\end{abstract}

\section{Keywords}

Johann Heinrich Schmelzer, Nicolò Minato, Leopold I, Imperial court, Laxenburg, Italian opera, dramatico-musical works, serenatas 
It has been more than one hundred years since Egon Wellesz's study about ballet music by Johann Heinrich and Anton Andreas Schmelzer, which triggered greater interest in the personality and work of this composer, was published. ${ }^{1}$ Nowadays, Schmelzer is undoubtedly one of the most famous composers of the European middle Baroque period. ${ }^{2}$ However, his vocal-instrumental work, particularly secular dramatico-musical compositions are still hidden in library and archive depositories. Even though it is a small group of compositions, they contribute to a more complex view of the composer's work, his courtly obligations and the issue of adaptation to the Italian style which dominated at the imperial court. These circumstances and the connection of the two serenatas with Czech musical history are the crucial points for further research. ${ }^{3}$ The works of Ulrike Hofmann and Herbert Seifert can be considered as model studies in this case. ${ }^{4}$

Currently we are aware of a total of four secular dramatico-musical works by Schmelzer. The music is still in existence for three of them; only a printed libretto has survived for the fourth one. ${ }^{5}$

\begin{tabular}{|l|l|l|l|l|}
\hline Title & Genre & Year & Occasion & Sources \\
\hline $\begin{array}{l}\text { Hercules } \\
\text { und Onfale }\end{array}$ & serenata & 1676 & $\begin{array}{l}\text { Engagement of } \\
\text { Maria Antonia }\end{array}$ & Parts \\
\hline L'urna della sorte & ossequio musicale & 1677 & Emperor's birthday & Libretto \\
\hline $\begin{array}{l}\text { Le veglie } \\
\text { ossequiose }\end{array}$ & serenata & 1679 & Emperor's birthday & Score \\
\hline $\begin{array}{l}\text { Die siben Alter } \\
\text { stimmen } \\
\text { zusammen }\end{array}$ & serenata & 1680 & $\begin{array}{l}\text { Maria Antonia's } \\
\text { birthday }\end{array}$ & Particell \\
\hline
\end{tabular}

Table 1 Dramatico-musical works by Schmelzer

All of them are typical congratulatory compositions from the second half of the $17^{\text {th }}$ century. ${ }^{6}$ They are one-act dramatic pieces; their texts primarily involve congratulations, tributes and commentary on current political affairs with a simple dramatic storyline. In

1 WELLESZ, Egon. Die Ballet-Suiten von Johann Heinrich und Anton Andreas Schmelzer: ein Beitrag zur Geschichte der Musik österreichischen Hofe im 17. Jahrhundert. Wien: Alfred Hölder, 1914.

2 SCHNITZLER, Rudolf. Schmelzer, Johann Heinrich. In The New Grove Dictionary of Music and Musicians, vol. 22, Stanley Sadie, John Tyrrell (eds.). 2nd edition, London: Macmillan, 2001, p. 526.

3 While the instrumental and vocal parts of Schmelzer's first serenata are housed in Kroměříž Archiepiscopal archives, his last serenata was first performed in Prague in 1680.

4 HOFMANN, Ulrike. Die Serenata am Hofe Kaiser Leopold I. 1658-1705. Dissertation thesis. Wien: Universität Wien, 1975 and SEIFERT, Herbert. Die Oper am Wiener Kaiserhof im 17. Jahrhundert. Tutzing: Verlegt bei Hans Schneider, 1985. Regarding the Prague stay of Imperial court in 1679-1680 several works by Marc Niubò are contributive as well, for example NIUBÒ, Marc. Leopold I. a hudba císařského dvora v Praze v letech 1679-1680. In Barokni Praha - barokni Čechie 1620-1740: sbornik přispěvků z vědecké konference o fenoménu baroka v Čechách, Praha, Anežský klášter a Clam-Gallasův palác, 24.-27. záŕí 2001. Olga Fejtová et al. (eds.). Vyd. 1. Praha: Scriptorium, 2004, p. 95-131.

5 A significant period handwritten inventory called Distinta specificatione dell'archivio musicale per il servizio della cappella, e camera cesarea does not mention more examples of Schmelzer's dramatico-musical compositions. See: A-Wn, Suppl. Mus. M2451.

6 According to detailed characteristic mentioned in HOFMANN, op. cit., p. 30, 42, 55-65. 
the Italian serenatas - in both cases composed for Leopold I - there are only allegoric, often quite bizarre characters. ${ }^{7}$

Schmelzer composed his first dramatico-musical work in 1676. It is a serenata in German to celebrate the engagement of archduchess Maria Antonia (1669-1692). In this case uniquely preserved vocal and instrumental parts depict the whole appearance of a festive serenata from "leopoldian" $\mathrm{era} .{ }^{8}$ Regarding vocal-instrumental pieces in German, the choice of Schmelzer as a composer is understandable. ${ }^{9}$ But as a court composer, he also had to be able to set Italian texts, which was also required on several occasions. The reason for this was probably workload of the then bandmaster of the Empress dowager - Antonio Draghi (ca. 1634-1700). For example, in 1677 Draghi had to compose five drammi per musica, a musical academy, one sepolcro, two serenatas and one Introduzione ad un balletto. Therefore, Schmelzer was probably asked to compose one serenata (as well as two sepolcros and ballet music for Draghi's drammi per musica as usual), while Empress dowager's court organist Giovanni Battista Pederzuoli (c. 1630-1689) composed a birthday festa teatrale for Empress Eleonora Magdalena. ${ }^{10}$

Schmelzer's work L'urna della sorte was performed on 9 June 1677 - on the day of the Emperor's birthday, ${ }^{11}$ and before Draghi's three-act birthday dramma per musica Adriano sul Monte Casio (performed on 27 June). As already mentioned, only a libretto for this serenata has survived the years. It is worthy of attention mainly for its unusual topic, and in order to evaluate dramatic action in serenatas from the second half of the $17^{\text {th }}$ century. L'urna della sorte - The ballot box of fate has a subtitle: ossequio musicale - a musical tribute. Right at the beginning of the piece, the name of the celebrated Emperor is pronounced. ${ }^{12}$ Then his virtues and heroic deeds are extolled; tributes are delivered throughout the piece, as it was typical for all period congratulatory pieces. ${ }^{13}$ The argomento in the

7 For example Il Silentio notturno (Night silence) or Desiderio dell'Universo (Desire of the Universe). Other examples of typical allegoric characters in "Leopoldian" serenata could be L'Anno 1680 (The Year 1680) or $I l$ Giorno 9 di Giuno (The Day of $9^{\text {th }}$ June) in serenata Gli oblighi dell' universo performed in Pardubice on 9 June 1680, see A-Wn, Mus. Hs. 17925.

8 Music for the serenata L'urna della sorte is missing, two instrumental Sinfonias for serenata Le veglie ossequiose are not written within the preserved score and the score for Schmelzer's last dramatico-musical work Die sieben Alter stimmen zusammen is reduced for selected voices and B.c. part, as majority of scores from the so called "Bibliotheca Cubicularis" (Schlafkammerbibliothek) of Emperor Leopold I.

9 Schmelzer composed in total two German serenatas and also two German sepolcros, see: SLOUKA, Petr. Německojazyčné holdovací serenaty Johanna Heinricha Schmelzera. In Cantantibus organis: hudebni kultura raného novověku ve středoevropských souvislostech: ad honorem Jiř́ Sehnal. Brno: Moravská zemská knihovna v Brně, 2016, p. 71-78 and SLOUKA, Petr. Hudebnědramatický provoz na dvoře císaře Leopolda I. In Koněv piškotech. Slaunosti na dvoře císaře Leopolda I. Kateřina Fajtlová - Miroslav Kindl (eds.). Olomouc: Muzeum umění Olomouc, 2017, p. 26-27.

10 SEIFERT, op. cit., p. 486-490 and KÖCHEL, Ludwig. J. J. Fux. Hofcompositor und Hofkapellmeister der Kaiser Leopold I., Josef I. und Karl VI. von 1698 bis 1740. Wien: A. Hölder, 1872, 499-500.

11 See the title page of printed libretto: A-Wn, 407381-A.Adl.3, a score is missing.

12 Al desio del' Vniuerso, di LEOPOLDO al merto insigne, Dea, che puoi bear chi vuoi, non tener il crin auuerso, mostra ciglia più benigne $[. .$.$] .$

13 It is a common type of dramaturgy of congratulatory serenatas not only in the second half of $17^{\text {th }}$ century, but in $18^{\text {th }}$ century as well. However the works from the period of reign of Emperor Charles VI are more influenced with the „Imperial style“ programmatic. See more in VESELÁ, Irena. Císařský styl v hudebně-dramatických 
libretto briefly introduces the storyline of the work. The virtues of Emperor Leopold hold a lottery in which they draw three happy events from the ballot box of fate that the goddess Fortuna grants him in that year. The name of the librettist does not appear on the libretto. By its style, for example according to the dynamic flow of the plot, inventive allegories with touch of sarcasm and using of refrains to highlight several important phrases, a possible author might be court poet Nicolò Minato (1627-1698). ${ }^{14}$ The style of the text of court historian Girolamo Branchi (?-?), who created a single libretto that year of which we are aware, and who employed a similar theme of drawing lots for prophecy, is different, as he does not seem to be proficient in writing texts of congratulations. ${ }^{15}$ Branchi's festa teatrale I presagii della Sorte - The Prophecy of Fate was composed by above mentioned Giovanni Battista Pederzuoli for birthday celebrations of Empress Eleonora Magdalena in command of the Empress dowager, while her kapellmeister Antonio Draghi accompanied the Emperor to Passau in that time. ${ }^{16}$

\begin{tabular}{|l|l|l|l|l|}
\hline Character & Character - translation & Number of arias & Number of duets & Number of trios \\
\hline $\begin{array}{l}\text { Desiderio } \\
\text { dell'Universo }\end{array}$ & Desire of the Universe & 0 & 2 & 0 \\
\hline Merito & Merit & 0 & 2 & 0 \\
\hline Fortuna & Fortuna & 1 & 0 & 0 \\
\hline Sapienza & Wisdom & 1 & 0 & 1 \\
\hline Prudenza & Deliberation & 1 & 0 & 1 \\
\hline Bontà & Goodness & 1 & 0 & 1 \\
\hline
\end{tabular}

Table 2 L'urna della sorte - characters

A total of six allegorical characters and a choir appear in the serenata L'urna della sorte. Desiderio dell'Universo, with Merito, appeals to Fortuna to hear out the desire of the universe, and to show this ruler its favourable side. Fortuna asks what she is guilty of because she has always been on the side of this Emperor. Desiderio steps out and openly responds that the peace in the country is disturbed by rebellious Hungarians and impudent Frenchmen. ${ }^{17}$ Fortuna thereupon refers to the mythical heroes who were made famous thanks to their enemies. Merito then comes up with probably the most pressing reproach. The prayers of the whole world have failed so far to ensure any offspring to the emperor.

dílech provedených za pobytu císaře Karla VI. v českých zemích roku 1723. Dissertation thesis. Brno: Masaryk University, 2007, p. 18-34 and TALBOT, Michael. Serenata. In The New Grove Dictionary of Music and Musicians, vol. 23, Stanley Sadie, John Tyrrell (eds.). 2nd edition, London: Macmillan, 2001, p. 113-115.

14 ROSAND, Elen-SEIFERT Herbert. Nicolò Minato. In The New Grove Dictionary of Music and Musicians, vol. 16, Stanley Sadie, John Tyrrell (eds.). 2nd edition, London: Macmillan, 2001, p. 710-711 and NOE, Alfred. Minato, Nicolò (Nicola). In Oesterreichisches Musiklexikon, Band 3, Wien: Verlag der Österreichische Akademie der Wissenschaften, 2004, p. 1447.

15 Up to now, only this particular libretto by Branchi is known: A-Wn, MF 6048. As far as I know, he also wrote the text for cantata Occhi miei, non vi struggete, which is preserved in A-Wn, under call number Mus. Hs.17768/1-8. See HARRANDT, Andrea. Branchi (Bianchi), Girolamo. In Oesterreichisches Musiklexikon, Band

1, Wien: Verlag der Österreichische Akademie der Wissenschaften, 2002, p. 196

16 SEIFERT, op. cit., p. 83.

17 Pur; li turban la Pace, I Pannoni rubelli, e’l Gallo audace. 
Fortuna emphasizes that simple plants grow fast, but noble plants and pines spread their branches only after the loss of many scions. Fortuna promises her favour to the Austrian house. Sapienza, Prudenza, and Bontà arrive. Fortuna challenges them and they approach the ballot box of fate and each of them draws one event. In three scenes, they draw lots with Victory, Peace and Son. Then, together with the other characters, they praise the day that the emperor was born. ${ }^{18}$

The ability to create a truly impressive dialogue among the characters from a quite simple topic that is full of novel allegories and comments on the current political situation proves remarkable. The Emperor is not only mentioned by name here but also as a hero with ancient connotations (Caesar and Augustus) who should be wreathed with laurels and whose deeds are comparable to those of the mythological heroes. However, he himself is seen as a humble ruler who possesses all the mentioned virtues because (as the prophecy suggests) his pleasure will be Victory for the sake of establishing the desired Peace and producing an Offspring, which will ensure the succession and thus the welfare of the country.

If the music for this piece had survived, it would have been interesting to hear this composition, because the libretto offers many tense dramatic situations. Besides the "complaints" of Desire and Merit in the beginning, which are solo parts with the common repetition of opening and closing verses - a kind of chorus - the concerned recitative is Fortuna's. In this recitative, she emphasizes her endless favour for the ruling house to finally surrender and challenge the Virtues to the drawing of lots. Fortuna also has the other larger recitative and it is a licenza before the final choir. The individual drawings that have the same structure are then the strong dramatic moments. The structure emerges from the tension of the characters, which is a short dynamic dialogue, then the announcement of the prophecy and a cheerful aria of the selected Virtue who drew the prophecy. It is exactly in this part of the serenata where the libretto provides valuable testimony about the scenic or partially staged performance of these works in the period of Leopold I's rule.

The librettos of one-act serenatas do not involve segmentations of scenes nor their descriptions or staging and dramaturgical notes. Such indications must therefore be sought in the text itself. Aside from the fact that there are characters which are already characterized by their names, and we can therefore assume they would be symbolically stylized by costumes and other attributes, we can find instructions like these in the text: Cotesta è l'Urna De la Sorte: Traete Voi le Felicità (This is the ballot box of fate: Draw what his fortunes should be) or Sciogli il Papiro; e leggi omai (Unwind the paper and read already). These would be quite illogical if the piece were to be performed only as a concert.

Schmelzer's second serenata on an Italian text, Le veglie ossequiose, is preserved in the

18 From the „librettist's prophecy, only the vision of long-desired heir was fulfilled. A son named Joseph, later Emperor Joseph I, was born on 26 July 1678. In the same year, Immrich Tököli's revolt broke out in Hungary, which was suppressed after nearly 9 years. The war with France was finished just 1679 at the Peace of Nijmegen with certain territorial losses of Austrian Monarchy. That conflict was renewed in 1688, when a new war - so called "Nine-years War" - was proclaimed. For more see: MIKULEC, Jiří. Leopold I. Život a vláda barokniho Habsburka. Praha: Paseka, 1997, p. 61-72, 85-97. 
form of a score from the so-called Schlafkammerbibliothek - only the introductory Sinfonia and Sonata for the duet of Virtù and Fortuna are missing. ${ }^{19}$ The printed libretto is not preserved but the score contains some valuable additional information. Its title page states that the piece was performed on the day of Emperor Leopold's birthday in the evening, i.e. on 9 June 1679, su l'aqua della fossa del Castello dell'Imperial Parco di Laxenburg, so again in Laxenburg but on the moat surface in the castle park. ${ }^{20}$ In the case of Le veglie ossequiose we also know both the composer and the author of the libretto. The name of court poet Nicolò Minato appears on the title page. Imaginative and usually political allegories, funny oppositions and a dynamic flow of events are typical of his craftsmanship. As in 1677, for the Emperor's birthday the three-act drama per musica Curzio by Antonio Draghi was rehearsed. However, because of the plague epidemic Curzio was not performed. Already in September the Imperial court was moved to Prague to escape that epidemic. ${ }^{21}$

\begin{tabular}{|l|l|l|l|l|l|}
\hline Character & $\begin{array}{l}\text { Character - } \\
\text { translation }\end{array}$ & Type of voice & $\begin{array}{l}\text { Number of } \\
\text { arias (ariosos) }\end{array}$ & $\begin{array}{l}\text { Number of } \\
\text { duets }\end{array}$ & $\begin{array}{l}\text { Number of } \\
\text { ensembles }\end{array}$ \\
\hline Fortuna & Fortuna & Soprano & 2 & 3 & 2 \\
\hline Virtù & Virtue & Soprano & $1+2$ & 3 & 2 \\
\hline Giubilo & Jubilation & Alto & 1 & 2 & 2 \\
\hline Piacere & Delight & Tenor & 1 & 2 & 2 \\
\hline II Silentio notturno & Night silence & Baritone & 1 & 0 & 2 \\
\hline
\end{tabular}

Table 3 Le veglie ossequiose - characters

Five allegorical characters are in the serenata. Four of them - Fortuna, Virtù, Giubilo and Piacere praise the place where they appear as they sing - on the watery surface which surrounds noble walls. ${ }^{22}$ The plot is therefore situated in the place of its performance. Fortuna comes and exhorts Apollon: Slake your rays, fair-haired god, a hero bringing greater light was born. Hide in the west, look at the noble glory of the Austrian hero! ${ }^{23}$ By this, she wakes up Il Silentio notturno (Night silence), which berates the characters: why do they disturb the evening when they can celebrate during day? Virtù then utters the central idea of the serenata together with the purpose of its performance - the day is too short

19 See A-Wn, Mus.Hs.16913. Separated scores or parts were most likely used for performances of those pieces. Unfortunately, they are preserved rather rarely. See WELLESZ, Egon. Die Opern und Oratorien in Wien 1660-1708. Wien: Artaria \& Co., 1918, p. 5-6. About problematic of scores and parts from the possession of Leopold I, their appearance, etc. see: LEIBNITZ, Thomas. Die Musik der Kaiser im Spiegel der Wiener Hofmusikkapelle. In Spettacolo Barocco! Triumph des Theaters. Wien: Michael Imhof Verlag, 2016, p. 126-127 and GMEINER, Josef. Die „Schlafkammerbibliothek“ Kaiser Leopolds I. In Biblos. 43, (3-4). Wien: Biblos, 1994, p. 199-212.

20 For other exceptional places of operatic performances at the Imperial Court see: SEIFERT, op. cit., p. $387-427$.

21 MIKULEC, op. cit., p. 119-125 and HAVLÍK, Jiří. Jezuité a morové epidemie 1562-1713. In Jezuité a Klementinum. A. Richterová et I. Čornejová (eds.), Praha: NK Praha, 2006, p. 39-42.

22 Sù quest'onda - che circonda Mura, Auguste passiam l'hore [...]

23 Tu pur copri in Occidente, Vago Apollo, i smorti rai. Dell'Austriaco Eroe splendente L'alta gloria ogn'or vedrai. 
to celebrate Leopold's birthday. Then the individual characters introduce Il Silentio and assure him that they are not going to give up their cheering and festivity. Piacere asks people to celebrate the birth of a hero, which interrupted the stable course of the day in the recitative, and he refers to the prolongation of evening when Hercules was conceived. In this moment, Il Silentio changes his opinion and agrees to stay awake because even the silence becomes talkative at the birth of Augustus. Virtù utters the congratulation Viva eterno Leopoldo! in her final aria with the function of licenza. The final choir wishes the Emperor happiness and stresses that he is praised by the heavens and the whole world is obedient to him.

Minato based the whole libretto on the idea that no day was sufficiently long to celebrate the birth of Emperor Leopold. Right at the beginning he mentions the archenemy of the emperor, Louis XIV. ${ }^{24} \mathrm{He}$ is hidden behind the Apollon in the West. Leopold's birth lights up the night, and the wakefulness of the participating characters will prolong the day. In the given circumstances, the initially morose Night silence will also join the celebrations. This change of the day's course is not random and unique. Jupiter also prolonged the night when he engendered Hercules with Alcmene. ${ }^{25}$ Many other allegories are present in the libretto and they are brilliantly associated with the Emperor's attributes. Among them, we can mention a word play in which the arcs of triumph and the curves of bows are asked to praise the Emperor - alluding both to his ability to win on the battlefield and to master the musical arts.

The libretto offered Schmelzer a space to apply his dramatic abilities. There are two longer recitatives, one of which is dialogic. Other texts are set to music in the form of arias, ariosos, duets, a short recitative con stromenti, which is converted to an aria accompanied by three violas and ensembles, i.e. choirs. All of these forms change very quickly or mingle with one another to escalate the tension, similarly to the composer's German serenatas. It is also characteristic of Schmelzer's dramatico-musical works to use a distinct, tuneful melody line in ariosos, arias and ensemble performances. This procedure of composition is far more obvious in the German serenatas and sepolcros, the arias and ensembles of which are rather impressive simple strophic songs of a dance-like nature. The text-setting is syllabic in this case. ${ }^{26}$

Tuneful melodies and dance-like features of music performances also prevail in the serenata Le veglie ossequiose, but there are two pieces that do not exhibit these characteristics and are formally close to the ariosos and arias by Antonio Draghi, Carlo Cappelini and other Italian composers of the imperial court. ${ }^{27}$ Those are the arioso of Virtù

24 BASTL, Beatrix et al. (eds.). Habsburkové. Země Koruny české ve středoevropské monarchii: 1526-1740. 1st edition, Praha: Nakladatelství Lidové noviny, 2017, p. 149-150.

25 The night Jupiter passed with Alcmena was prolonged to three long nights. ZAMAROVSKÝ, Vojtěch. Bohové a hrdinové antických bájí. Praha: Nakladatelství Deus, 2013, p. 36, 168.

26 The same compositional technique was used in Schmelzer's ecclesiastical works. In the pastoral Christmas motet Currite, accurrite we can find only two shorter melismas. Startlingly, its final Alleluja was set to music in syllabical way as well. In the motet Inquietum est cor meum there is only short melisma on the verb cantabimus. CZ-Kra, A 265 and A 230.

27 A-Wn, Mus. Hs. 16913 
"Dunque lietei, e festosi" and Virtù's aria "Lieta parca fili sempre". Their text-setting is not strictly syllabic and there is also a cheerful ascending two-bar melisma to highlight the word corde in the Virtù's arioso.

Virtu

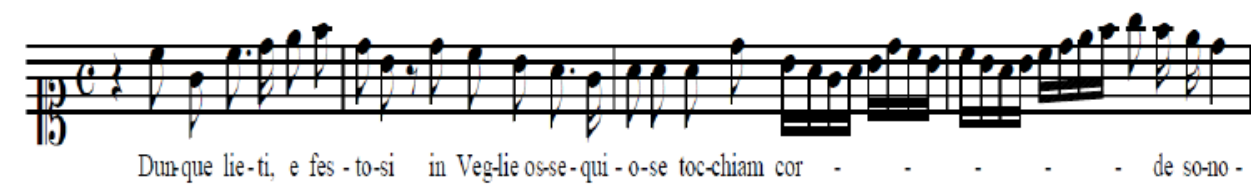

Sample 1 Arioso of Virtù

Schmelzer furthermore applies polyphonic entrances of voices in several ensembles, similarly to Antonio Draghi in some cases, and he alternates them with homophonic passages. Due to the absence of ensemble passages in Hercules und Onfale and a Particell of Die sieben Alter stimmen zusammen, it is not possible to find out if he also set passages with multiple voices similarly in German serenatas. The same procedure can be found in the instrumental ritornellos of Le veglie ossequiose. Those have five voices without distinction. Similarly to Draghi, Schmelzer employs a motif that quotes the introductory motif of the aria or a variant of it. After a polyphonic entrance of voices (which appears in several ritornellos), a homophonic part follows. At the end of the ritornello, the introductory motif of the aria recurs.

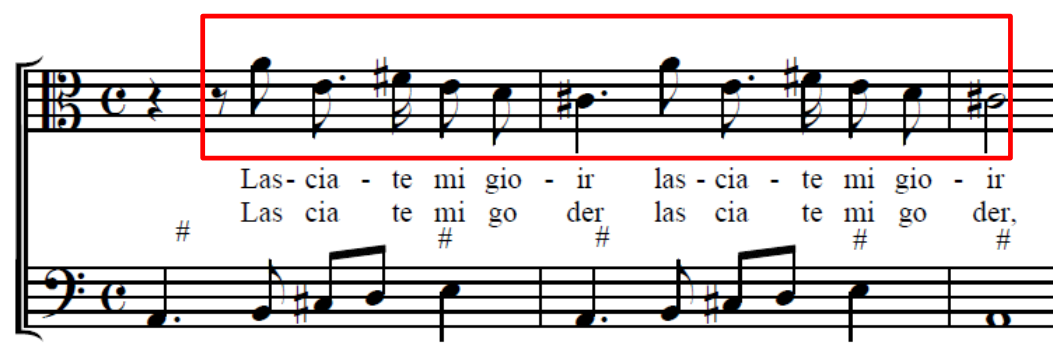

Sample 2 Aria of Giubilo

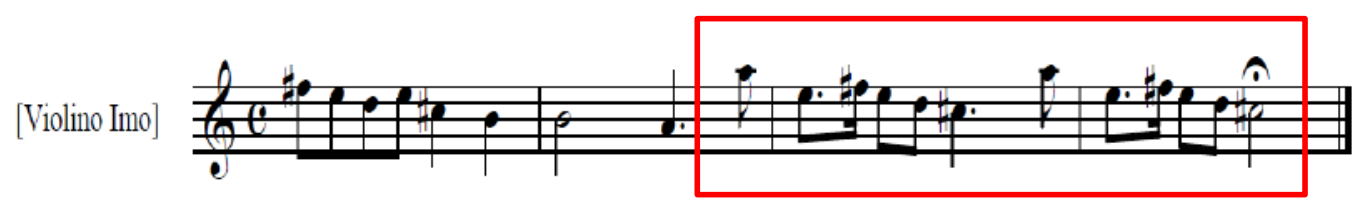

Sample 3 Ritornello, at the end the introductory motif of the Giubilo's aria

By comparison, the works in German quote the motif of an aria in the ritornello with very few exceptions, and the ritornellos are mostly homophonic. 


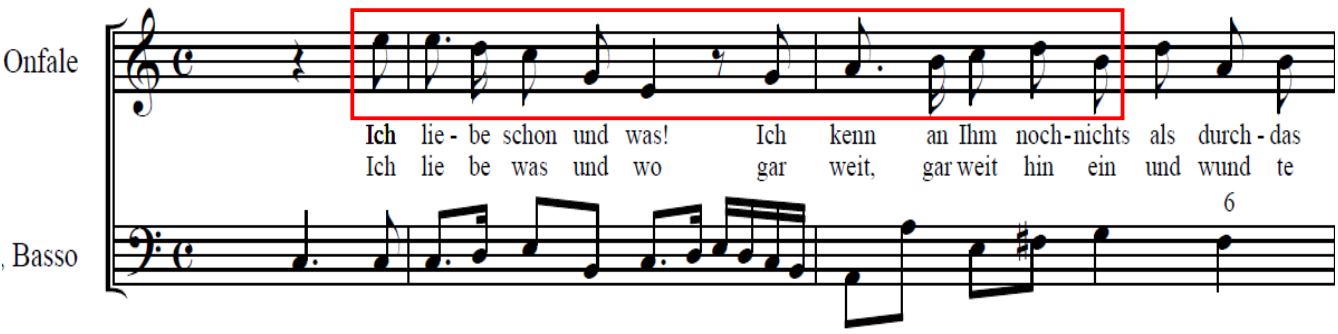

Sample 4 Onfale's aria from Hercules und Onfale $e^{28}$

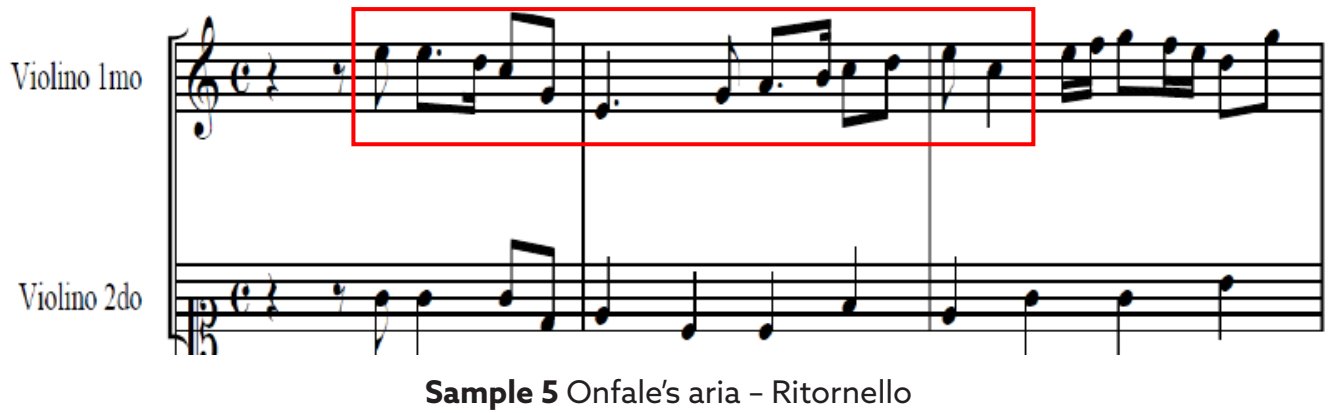

Schmelzer's emphasis on lyricism in the arias and a rather syllabic setting of text to music prevented a greater usage of rhetorical musical figures. There are also no onomatopoeic passages as in pieces by his Italian colleagues. In some places, hypotyposis figures that "optically" depict the text are applied, mainly in recitatives. ${ }^{29}$ But a statement by Ulrike Hofmann, who claims that this procedure of composition is to the detriment of the emotional expression contained in the text, certainly cannot be supported. ${ }^{30}$ The emotions are embedded in the relevant keys Schmelzer chooses (given the celebratory and cheerful nature of the pieces, he selects the keys of merriment and of martial nature, which are C major, G major, and D major; but also a minor and e minor tonalities, which express seriousness and kindness), and also in the forms of dances on which the arias are based - sarabandes, courantes, allemandes and menuets. ${ }^{31}$ His expression of the meanings of words through compositional techniques is also interesting - e.g., applying polyphony for the words "a le sue Fortune" (his luck), which depicts the nature of fickle Fortuna and the subsequent harmonizing of voices in the connection of "mondo" (the world). The larger number of characters interpreting the essential parts of the text, exclamations or cheering

28 CZ-Kra, A 928.

29 SCHÜLLEROVÁ, Silvie. Afektová teorie a hudebně rétorické figury. Dissertation thesis. Brno: Masaryk University, 2006, p. 149.

30 HOFMANN, op. cit., p. 136.

31 SCHÜLLEROVÁ, op. cit., p. 63-66, 70-72. 
must have been impressive for listeners, as well as multiple repetitions of certain words in homophony with multiple voices, which emphasize their meanings.

The serenatas by Johann Heinrich Schmelzer offer a valuable source of information about the compositions of an opera type by a non-Italian composer in an environment where the Italian style prevailed. Schmelzer was together with Emperor Leopold the only Austrian composer at the court who composed dramatico-musical works until Johann Joseph Fux, Georg Reutter and others appeared. The simplicity of the compositions, distinctive nature of the arias, and syllabic text-setting, which we can say are the typical features of his style, all derive from his main occupation - which was as a composer of dance music - as well as from composing German songs, but also from the specific purposes for which he created his dramatico-musical compositions. We can see a partial influence from the compositional procedures of Italian authors producing Italian serenatas at the court, which is undoubtedly due to its central personage - Leopold I - who was an admirer of the Venetian style. ${ }^{32}$ Nevertheless, the signs of virtuosic passages in the singing parts, imitative principles, or short polyphonic passages did not significantly distort Schmelzer's original style. The characteristic, almost rustic nature which is so obvious in serenatas in German - is dominant here as well as in his motets and sepolcros, and it was destined to cease to exist together with the composer himself. ${ }^{33}$

\section{Bibliography}

\section{Sources}

Currite, accurrite. CZ-Kra, A 265.

Distinta specificatione dell'archivio musicale per il servizio della cappella, e camera cesarea. A-Wn, Suppl. Mus. M2451.

Gli oblighi dell' universo. A-Wn, Mus. Hs. 17925.

Hercules und Onfale. CZ-Kra, A 928,

Inquietum est cor meum. CZ-Kra, A 230.

I presagii dalla sorte. A-Wn, MF 6048; other exemplar available in Österreichisches Theatermuseum, under call number 792410-B.4.

L'urna della sorte. A-Wn, 407381-A.Adl.3.

Le veglie ossequiose. A-Wn, Mus. Hs. 16913.

32 LEIBNITZ, op. cit., p. 121-123.

33 My sincere thanks belong to Jana Perutková for all her support and valuable consultations and to Ondřej Macek for his kind help with translation of Italian librettos as well. 


\section{Literature}

BASTL, Beatrix et al. (eds.). Habsburkové. Země Koruny české ve středoevropské monarchii: 1526-1740. 1st edition, Praha: Nakladatelství Lidové noviny, 2017.

GMEINER, Josef. Die "Schlafkammerbibliothek" Kaiser Leopolds I. In Biblos, 43, (3-4). Wien: Biblos, 1994.

HADAMOWSKY, Franz. Barocktheater am Wiener Kaiserhof 1625-1740. Mit einem Spielplan. In Jahrbuch der Gesellschaft für Wiener Theaterforschung. Wien: A. Sexl, 1952.

HARRANDT, Andrea. Branchi (Bianchi), Girolamo. In Oesterreichisches Musiklexikon, Band 1, Wien: Verlag der Österreichische Akademie der Wissenschaften, 2002.

HAVLÍK, Jiří. Jezuité a morové epidemie 1562-1713. In Jezuité a Klementinum. A. Richterová et I. Čornejová (eds.), Praha: NK Praha, 2006.

HOFMANN, Ulrike. Die Serenata am Hofe Kaiser Leopold I. 1658-1705. Dissertation thesis. Wien: Universität Wien, 1975.

KÖCHEL, Ludwig. J. J. Fux. Hofcompositor und Hofkapellmeister der Kaiser Leopold I., Josef I. und Karl VI. von 1698 bis 1740. Wien: A. Hölder, 1872.

LEIBNITZ, Thomas. Die Musik der Kaiser im Spiegel der Wiener Hofmusikkapelle. In Spettacolo Barocco! Triumph des Theaters. Andrea Sommer-Mathis - Daniela Franke - Rudi Risatti (eds.). Wien: Michael Imhof Verlag, 2016.

MIKULEC, Jiří. Leopold I. Život a vláda barokniho Habsburka. Praha, Litomyšl: Paseka, 1997.

NIUBÒ, Marc. Císařský dvuir v Praze v letech 1679-80 a oratorium o svatém Václavovi. Diploma thesis. Praha: FFUK, 2000.

NIUBÒ, Marc. Leopold I. a hudba císařského dvora v Praze v letech 1679-1680. In Barokni Praha - barokni Čechie 1620-1740: sbornik př́spěvkĩ z vědecké konference o fenoménu baroka v Čechách, Praha, Anežský klášter a Clam-Gallasưv palác, 24.-27. zář́ 2001. Olga Fejtová et al. (eds.). Vyd. 1. Praha: Scriptorium, 2004.

NOE, Alfred. Minato, Nicolò (Nicola). In Oesterreichisches Musiklexikon, Band 3, Wien: Verlag der Österreichische Akademie der Wissenschaften, 2004.

ROSAND, Elen-SEIFERT Herbert. Nicolò Minato. In The New Grove Dictionary of Music and Musicians, vol. 16, Stanley Sadie, John Tyrrell (eds.). 2nd edition, London: Macmillan, 2001.

SCHÜLLEROVÁ, Silvie. Afektová teorie a hudebně rétorické figury. Dissertation thesis. Brno: Masaryk University, 2006.

SCHNITZLER, Rudolf. Schmelzer, Johann Heinrich. In The New Grove Dictionary of Music and Musicians, vol. 22, Stanley Sadie, John Tyrrell (eds.). 2nd edition, London: Macmillan, 2001.

SEHNAL, Jiří - PEŠKOVÁ, Jitřenka. Caroli de Liechtenstein-Castelcorno episcopi Olumucensis operum artis musicae collectio Cremsirii reservata. Praha: Bibliotheca nationalis rei publicae Bohemicae and Editio Supraphon, 1998.

SEHNAL, Jiří. Pavel Vejvanovský and the Kroměřž music collection. Perspectives on seventeenth-century music in Moravia. Olomouc: Palacký University in Olomouc, 2008.

SEHNAL, Jiří. Streicherstimmen in den Sonaten der Lichtensteinschen Musiksammlung in Kremsier. In SALMEN, Walter (ed.). Kontrabaß und Baßfunktion: Bericht über die vom 28. 8. bis 30. 8. 1984 in Innsbruck abgehaltene Fachtagung. Innsbruck: Edition Helbing, 1986, s. 71-76.

SEIFERT, Herbert. Die Oper am Wiener Kaiserhof im 17. Jahrhundert. Tutzing: Verlegt bei Hans Schneider, 1985.

SEIFERT, Herbert. Der Sig-prangende Hochzeit-Gott. Hochzeitsfeste am Wiener Kaiserhof 1622-1699. Wien: Musikwissenschaftlicher Verlag Wien, 1988.

SLOUKA, Petr. Německojazyčné holdovací serenaty Johanna Heinricha Schmelzera. In Cantantibus 
organis: hudebni kultura raného novověku ve středoevropských souvislostech: ad honorem Jiř́ Sehnal. Brno: Moravská zemská knihovna v Brně, 2016.

SLOUKA, Petr. Hudebnědramatický provoz na dvoře císaře Leopolda I. In Koně v piškotech. Slavnosti na dvoře císařre Leopolda I. Kateřina Fajtlová - Miroslav Kindl (eds.). Olomouc: Muzeum umění Olomouc, 2017.

TALBOT, Michael. Serenata. In The New Grove Dictionary of Music and Musicians, vol. 23, Stanley Sadie, John Tyrrell (eds.). 2nd edition, London: Macmillan, 2001.

VESELÁ, Irena. Císařský styl v hudebně-dramatických dílech provedených za pobytu císaře Karla VI. $v$ českých zemich roku 1723. Dissertation thesis. Brno: Masaryk University, 2007.

WELLESZ, Egon. Die Ballet-Suiten von Johann Heinrich und Anton Andreas Schmelzer: ein Beitrag zur Geschichte der Musik österreichischen Hofe im 17. Jahrhundert. Wien: Alfred Hölder, 1914.

ZAMAROVSKÝ, Vojtěch. Bohové a hrdinové antických báji. Praha: Nakladatelství Deus, 2013. 